\title{
CEO Tenure and Firm Performance in a Dynamic Environment: CEO Origin, CEO Power, and Strategic Change as Moderators
}

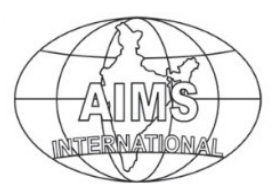

DOI: $10.26573 / 2019.13 .3 .2$

Volume 13, Number 3

September 2019, pp. 175-190

\author{
Dong Wook Huh \\ Amit Shah
}

Frostburg State University

(AShah@frostburg.edu)

Is long CEO tenure detrimental to firm performance in a dynamic environment? If it is the case, what factors may make long CEO tenure more or less harmful? We attempted to answer these questions by considering the moderating effects of CEO origin, $C E O$ power, and the degree of strategic change on the relationship between CEO tenure and firm performance. Focusing on the process through which the rigidity of CEO paradigm leads to strategic persistence and ultimately to lower firm performance, this paper shows that CEO origin, CEO power, and the degree of strategic change moderate the relationship in different mechanisms and directions. Using a sample of firms from the technology hardware and equipment industry in a period from 1998 to 2009, we found a much flatter inverted-U shaped relationship between CEO tenure and firm performance than that of previous research and CEO power and the degree of strategic change moderate the relationship.

Keywords: CEO Tenure, CEO Origin, CEO Power, CEO Paradigm, Strategic Change

\section{Introduction}

Is long CEO tenure detrimental to firm performance? The literature is largely consistent on the negative effect of long CEO tenure (Hambrick and Fukutomi, 1991; Henderson, Miller, and Hambrick, 2006; Miller, 1991; Miller and Shamsie, 2001; Wu, Levitas, and Priem, 2005; Hou, Priem, and Goranova, 2017). Empirical studies largely find that there is an inverted-U shaped relationship between CEO tenure and firm performance (Henderson et al., 2006; Miller and Shamsie, 2001; Wu, Levitas, and Priem, 2005). When does the peak performance occur during a CEO's tenure? According to Henderson et al. (2006), in the dynamic computer industry, which is characterized by rapid change of external conditions, the relationship between CEO tenure and firm performance was negative from year 1 . They argue that in a dynamic environment, CEO's opportunities for adaptive learning are extremely limited while external conditions change rapidly. The implication of their finding is troubling because it insinuates that the more often a firm in a highly dynamic environment replaces its CEO, the better off it will be.

In this paper, we attempted to reexamine the relationship between CEO tenure and firm performance in a dynamic environment. The paper was motivated by two 
questions. First, how harmful is long CEO tenure really? Second, if it is harmful, what factors may make long CEO tenure more or less harmful? To answer these questions, we considered CEO origin, CEO power, and the degree of strategic change as potential moderators on the relationship between CEO tenure and firm performance.

We drew on the concept of CEO paradigm (Hambrick and Fukutomi, 1991) to theorize about the relationship between CEO tenure and firm performance. We focused on the process through which the rigidity of CEO paradigm leads to strategic persistence and ultimately to lower firm performance. CEO paradigm rigidity and strategic persistence represent the psychological aspect and the behavioral aspect of the overall process respectively. Based on this theoretical foundation, we argue that CEO origin, CEO power, and the degree of strategic change moderate the relationship through different mechanisms.

We tested our hypotheses using a sample of CEOs of firms from the technology hardware and equipment industry in a 12-year period from 1998 to 2009. Primary reason for selecting this time period is to avoid/limit the effects of financial crisis that affected most all firms' performance from 2009 onwards.

The contributions of the study are threefold.

First, building on Hambrick and Fukutomi (1991) and Henderson et al. (2006), we look inside the concept of CEO paradigm in the perspectives of organizational knowledge and power. Even though Henderson et al. (2006) also base their theory on the concept of CEO paradigm, they do not address antecedents of the paradigm nor situational factors that make a CEO paradigm more or less potent. We examined the process through which CEO paradigm influences firm performance by considering CEO origin, CEO power, and the degree of strategic change.

Second, by emphasizing the importance of different types of knowledge and its implication in resource management processes, we theoretically link the role of CEO to the resource-based view (RBV) of the firm.

Third, by identifying potential moderators of the relationship between CEO tenure and firm performance, we provide insights on what it takes to prevent a CEO from going obsolete or at least delay the process of a CEO going obsolete in a dynamic environment.

\section{Theory and Hypotheses}

\subsection{CEO Tenure and Firm Performance}

Penrose (1959) characterizes the firm as both an administrative organization and a collection of productive resources. It follows then, that the firm's CEO is the head of this administrative organization and has the responsibility of managing the collection of productive resources. Because of the highly complex and ambiguous nature of the role of the $\mathrm{CEO}$ combined with bounded rationality of the $\mathrm{CEO}$, the CEO is assumed to operate with a finite model, or "paradigm", of how the environment behaves, what options are available, and how the organization should be run (Hambrick and Fukutomi, 1991).

According to Hambrick and Fukutomi (1991), there are different phases, "seasons", within an executive's tenure in a position and they create "distinct patterns of executive attention, behavior, and, ultimately organizational performance." They note that commitment to a paradigm generally increases from the first season on to 
the last season and posit that extremely short and extremely long CEO tenures will have harmful effects on firm performance.

Henderson et al. (2006) is an empirical test of the relationship between CEO tenure and firm performance based on the CEO paradigm concept developed in Hambrick and Fukutomi (1991). To examine the effect of industry dynamism on the relationship, they studied the CEOs in the relatively stable branded foods industry and in the highly dynamic computer industry. They found an inverted U-shaped relationship between CEO tenure and firm performance in the branded foods industry, consistent with Hambrick and Fukutomi (1991), but found a negative linear relationship between the two in the computer industry. CEO tenure has been also examined by a number of prior studies other than Hambrick and Fukutomi (1991) and Henderson et al. (2006). Miller (1991) maintains that long-tenured CEOs are not likely to achieve the fit between organization and environment that is necessary for good financial performance. Miller and Shamsie (2001), using the studio heads that ran all the major Hollywood film studios from 1936 to 1965 as the subjects, find that there exists an inverted U-shaped relationship between executive tenure and firm financial performance. Additionally, Wu, Levitas, and Priem (2005) find an inverted $\mathrm{U}$-shaped relationship between CEO tenure and firm invention.

We adopted the concept of CEO paradigm from Hambrick and Fukutomi (1991) to make a prediction on the relationship between CEO tenure and firm performance. To explain the relationship, we focused on the process through which CEO paradigm rigidity leads to strategic persistence and low firm performance. On average, as a CEO's tenure gets longer, his or her CEO paradigm will get more rigid. As the rigidity of the CEO paradigm strengthens, the firm's strategic persistence will intensify. This process will yield a positive impact on the firm's performance up to a point as the CEO paradigm solidifies, but its effect will later become harmful as the CEO paradigm becomes too rigid and strategic persistence too extreme while the industry environment goes through rapid change. Therefore, we hypothesize the following

Hypothesis 1 CEO tenure will have an inverted U-shaped relationship with firm performance in a dynamic industry.

\subsection{Moderating Role of CEO Origin}

CEO Selection As Henderson et al. (2006) note, in selecting a new CEO, the board of directors will try to find someone that is suitable for the conditions that the firm is facing at the time or expected to be exposed in the future. In a dynamic situation, this match is unlikely to be ideal or enduringly valid. This is the case because the board of directors' perspective on the conditions facing the firm will be incomplete at best. The directors may not understand the current environment fully well. Even if they do, their understanding will lose its validity quickly when the external environment does not evolve in ways that they anticipated. The likelihood of this happening will be higher in a dynamic industry.

Selecting an outside CEO is particularly risky in this dynamic environment. First, information asymmetry is typically a bigger problem for the board of directors when it evaluates an outsider than an insider. Evaluating an outside candidate will be much harder for the directors than evaluating an inside candidate (Harris and Helfet, 1997). The difficulty concerns not just an outside candidate's skills and personality traits, 
but also whether he or she fits well with the culture of an organization (Karaevli, 2007). Second, the decision to hire an outside CEO may cause a discontinuity so large that senior executives who were appointed by the predecessor CEO may decide to leave the firm or try to sabotage the changes initiated by the new CEO (Helmich and Brown, 1972; Shen and Cannella, 2002).

CEO Knowledge and Learning According to resource dependence theory (Pfeffer and Salancik, 1978), a CEO from outside the firm is desirable in that he or she is expected to bring valuable resources (i.e., knowledge and skills developed outside the firm) that can strengthen the firm or remedy the firm's problems. Scholars advocate hiring of an outside CEO to improve poor performance (Helmich and Brown, 1972) or deal with resistance to change (Pfeffer and Salancik, 1978).

In a dynamic environment, however, the positive effect of bringing external knowledge through hiring of an outside CEO may be limited for several reasons.

First, the nature of external knowledge that comes with the new outside CEO may not provide enduring benefits for the firm in a dynamic environment. Some aspects of the new CEO's knowledge may prove timeless, but those are exactly what the directors will have problems in evaluating. Firms usually expect to benefit from the new outside CEO's relatively novel knowledge and skills (Harris and Helfat, 1997; Zhang and Rajagopalan, 2010; Saidu, 2019). However, the novelty factor will typically lose its shine quickly in a dynamic environment. The kind of knowledge that is sought for in the new outside CEO tends to be fleeting. It will also need constant updating to remain valid.

Second, the new outside CEO will face a tremendously steep learning curve in understanding knowledge internal to the firm. Some aspects of this knowledge can certainly exist in codified forms, but most of it will either lose meaning or lead to misunderstandings when codified.

Third, to create value in a dynamic and uncertain environment, the firm should engage in three types of activities: (1) structuring the resource portfolio, (2) bundling resources to build capabilities, and (3) leveraging capabilities (Sirmon, Hitt, and Ireland, 2007). As the ultimate manager with the responsibility of managing the collection of productive resources, the CEO is supposed to oversee these activities. In so doing, he or she should be sensitive to the needs and consider feedback at each stage (Sirmon et al., 2007). With limited understanding of knowledge internal to the firm, the new outside CEO will have a hard time achieving superior value to customers through the resource management process.

Based on the arguments discussed above, we hypothesize the following

Hypothesis 2: CEO tenure will be more negatively associated with firm performance in the case of outside CEO than in that of inside CEO in a dynamic industry.

\subsection{Moderating Role of CEO Power}

CEO power may affect the relationship between CEO tenure and firm performance by boosting the potential of CEO hubris (Hayward and Hambrick, 1997). Specifically, if the CEO is regarded extremely important and powerful compared to the rest of the top management team members, his or her paradigm will tend to become rigid rather quickly. Moreover, without proper checks and balances from the rest of the top executives and board members, his or her paradigm will dominate the 
decision-making process. Therefore, higher CEO power may result in higher CEO paradigm rigidity and higher strategic persistence. The negative effect of higher CEO power will become more problematic as CEO tenure gets longer since it may amplify the problems of long CEO tenure.

Therefore, we hypothesize the following

Hypothesis 3: CEO tenure will be more negatively associated with firm performance when CEO power is high than when CEO power is low in a dynamic industry.

\subsection{Moderating Role of Strategic Change}

Strategic change can be defined either as the change in a specific strategic dimension or as the overall change in multiple key strategic dimensions (Zhang and Rajagopalan, 2010). One way of measuring the degree of strategic change is to examine the pattern in a firm's resource allocation (Mintzberg, 1978). The change in the pattern in a firm's resource allocation in key aspects of its strategic profile can reveal the degree of its strategic change (Finkelstein and Hambrick, 1990).

The firm's resource allocation decisions cannot be considered independently from its resource management process. Some of the allocated resources should go toward structuring the resource portfolio (i.e., acquiring, accumulating, and divesting), while others are devoted to bundling (i.e., stabilizing, enriching, and pioneering) and leveraging resources (i.e., leveraging, mobilizing, and coordinating) (Sirmon et al., 2007). Sirmon et al. (2007) emphasize the importance of synchronization of the activities listed above. When the degree of strategic change is moderate, this synchronization will not pose a great challenge to the firm. However, if the degree of strategic change is too large, it is possible that the change actually becomes detrimental rather than beneficial to the firm. Time compression diseconomies (Dierickx and Cool, 1989) also work against too much strategic change in a short span of time.

The negative effect of high strategic change will be more evident as CEO tenure gets longer. In early years of CEO tenure, CEO paradigm may be relatively flexible and strategic persistence, so high degree of strategic change may not be too much of a problem. However, in later years, high strategic change will be combined with rigid CEO paradigm and high level of strategic persistence, impairing firm performance. Therefore, we hypothesize the following

Hypothesis 4: CEO tenure will be more negatively associated with firm performance in high degree of strategic change in a dynamic industry.

Figure 1 presents the overview of the study's theoretical model.

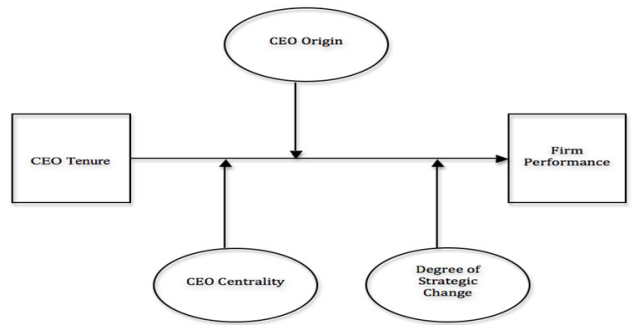

Figure 1 Theoretical Model 


\subsection{Sample and Data Sources}

\section{Method}

This study focuses on the relationship between CEO tenure and firm performance in a highly dynamic environment. To capture a highly competitive and dynamic environment as well as to control for possible industry effects, we drew our sample from the technology hardware and equipment industry represented by Standard \& Poor's Global Industry Classification Standard (GICS) index number 4520. The specific industry sectors covered include communications equipment (452010), computers and peripherals (452020), electronic equipment and components (452030), and office electronics (452040). Technology hardware and equipment industry is appropriate for the purpose of this study since it has the factors that contribute to environmental dynamism such as degree of innovation, technological change, supply instability, competitive rivalry, and market growth (Aldrich, 1979; Dess and Beard, 1984).

The list of the firms and their financial data from the study period were initially obtained from COMPUSTAT. Then these data were matched up with each firm's annual data on executives and their compensation available also from COMPUSTAT. To lessen the issue of missing data, supplemental data were collected from major public sources and firms' proxy statements. 362 CEOs from 172 firms were originally available from COMPUSTAT. Due to missing data, the sample that was used for this study included 169 firms and 316 CEOs from the fiscal year 1998 to 2009. It included 1,472 firm-years, but because of the need to calculate previous performance and strategic change, the number of firm-years was reduced further to 1,255 firm-years.

\subsection{Measures}

Firm Performance Firm performance was measured by Tobin's q, which compares the firm's market value to the replacement costs of its assets (Sirmon and Hitt, 2009). As a dynamic measure of firm performance, it is superior to solely accounting-based performance measures for the purpose of this study since it captures whether a firm is using scarce resources effectively (Lewellen and Badrinath, 1997), which is closely related to the relevancy of CEO paradigm. It also minimizes distortions arising from tax laws and accounting methods by combining market data with accounting data (Montgomery and Werner felt, 1988).

Tobin's q was calculated by dividing the sum of the firm's market value and the value of its long-term debt by the total book value of its assets (Kor and Mahoney, 2005) based on the data measured at the end of each fiscal year.

CEO Tenure CEO tenure is operationally defined as the years a chief executive had been in office (Henderson et al., 2006). It was measured by subtracting the year a $\mathrm{CEO}$ took the position from the current year.

CEO Origin CEO origin was captured based on the traditional dichotomous approach with two years as the threshold for inside/outside CEO (Cannella and Lubatkin, 1993; Harris and Helfat, 1997; Zhang and Rajagopalan, 2010). CEO origin was coded 1 if the firm's CEO had firm tenure of two years or more when he or she assumed the position or 0 otherwise. 
CEO Power The CEO pay slice (CPS) measure proposed by Bebchuk, Cremers, and Peyer (2007) was used as the proxy for CEO power. It was measured as the ratio of CEO's total compensation to the total aggregate compensation awarded to the firm's top five executives. In some cases, however, compensation data on less than five executives were available. In those cases, the compensation of the lowest paid executive was added to the aggregate until the total number of executives becomes five. The variable was then centered to make it easy to interpret the interaction effect with tenure.

Strategic Change Following the literature on strategic change (Carpenter, 2000; Finkelstein and Ham brick, 1990; Zhang, 2006; Zhang and Rajagopalan, 2010), we examined six strategic dimensions to create a composite measure of strategic change (1) advertising expenditures (divided by sales), (2) research and development expenditures (divided by sales), (3) expenditures on property, plant and equipment (measured by net PP\&E divided by gross PP\&E), (4) non-production overhead (measured by selling, general, and administrative (SGA) expenses divided by sales), (5) inventory levels (inventories divided by sales), and (6) financial leverage (debt divided by equity).

We followed Zhang and Rajagopalan (2010) to capture the level of strategic change. Specifically, we calculated the difference of each of these between the current and previous year to capture the annual change in each of the dimensions. Then we took the absolute values of the differences and standardize the absolute values within the sample. The average of the six standardized values was used as the measure of strategic change.

Control Variables We controlled for various firm and CEO characteristics to guard against possible confounding effects. Firm size was measured as the natural logarithm of the number of employees to control for economies of scale. The previous year's Tobin q was included in the models to control for prior firm performance. CEO duality was coded 1 if the CEO was also the chairman of the board of directors in the year and 0 otherwise. CEO age was measured by counting the years since a CEO was born.

Additionally, we used two dummy variables to account for the limitation of my sample. There were many missing values for R\&D and advertising in COMPUSTAT since firms that spend trivial amounts on these activities do not have to report them. We treated a missing value as zero, and then used the dummy variables to indicate that to remove any bias associated with it (Greene, 1993).

\subsection{Modeling and Estimation}

We analyzed the sample data using generalized estimating equations (GEE), which are appropriate "when inferences about the population are desired" (Greve and Goldeng, 2004). Since we are interested more in the general effects of tenure on firm performance, this approach matches the purpose of the study. Moreover, fixedeffects models were not appropriate in the analysis of the data since CEO tenure and CEO age move in lockstep with each other, confounding each other's effects. GEE models make it possible for these variables to be modeled together while controlling for unobserved differences across groups and provide very conservative results 
(Liang and Zeger, 1986).We used the XTGEE routine in STATA 12.0 with a Gaussian distribution and an identity link function.

\subsection{Data Analyses}

Table 1 lists means, standard deviations, and correlations for the dependent variable, control variables and independent variables. Table 2 lists the results of the main analyses.

Table 1 Descriptive Statistics and Correlation Matrix

\begin{tabular}{|ll|c|c|c|c|c|c|c|c|c|c|c|c|c|}
\hline & Vean & S.D. & 1 & 2 & 3 & 4 & 5 & 6 & 7 & 8 & 9 & 10 & 11 \\
\hline 1. & Firm performance & 2.13 & 3.93 & 1.00 & & & & & & & & & & \\
\hline 2. & CEO tenure & 7.30 & 7.28 & 0.03 & 1.00 & & & & & & & & & \\
\hline 3. & CEO origin (Insider $=1)$ & 0.54 & 0.50 & -0.06 & 0.14 & 1.00 & & & & & & & & \\
\hline 4. & CEO power (centered) & 0.00 & 0.14 & -0.05 & -0.14 & -0.05 & 1.00 & & & & & & & \\
\hline 5. & Firm size (logarithm) & 3.49 & 0.69 & -0.10 & -0.01 & 0.18 & 0.09 & 1.00 & & & & & & \\
\hline 6. & CEO duality & 0.48 & 0.50 & 0.03 & 0.36 & 0.03 & -0.05 & 0.13 & 1.00 & & & & & \\
\hline 7. & CEO age & 53.49 & 7.55 & -0.10 & 0.38 & 0.02 & 0.00 & 0.09 & 0.25 & 1.00 & & & & \\
\hline 8. & Strategic change & 0.00 & 0.52 & 0.07 & -0.09 & -0.11 & -0.05 & -0.35 & -0.09 & -0.12 & 1.00 & & & \\
\hline 9. & Advertising expenditure sing & 0.60 & 0.49 & 0.03 & -0.04 & 0.10 & 0.06 & 0.02 & -0.04 & 0.04 & -0.07 & 1.00 & & \\
\hline 10. & R\&D expenditure missing & 0.13 & 0.34 & -0.09 & 0.01 & 0.15 & 0.10 & 0.07 & 0.06 & -0.08 & -0.13 & 0.11 & 1.00 & \\
\hline 11. & Prior firm performance & 2.23 & 4.17 & 0.51 & 0.03 & -0.04 & -0.01 & -0.04 & 0.03 & -0.09 & 0.07 & 0.02 & -0.09 & 1.00 \\
\hline
\end{tabular}

Table 2 GEE Models for Firm Performance

\begin{tabular}{|l|l|l|l|l|l|l|l|l|l|l|l|l|l|l|}
\hline \multicolumn{1}{|c|}{ Performance } & \multicolumn{2}{|c|}{ Model 1} & \multicolumn{2}{c}{ Model 2 } & \multicolumn{2}{c|}{ Model 3 } & \multicolumn{2}{c|}{ Model 4 } & \multicolumn{2}{c|}{ Model 5 } & \multicolumn{2}{c|}{ Model 6 } \\
\hline CEO tenure & & & 0.069 & $* * *$ & 0.068 & $* *$ & 0.065 & $* *$ & 0.074 & $* * *$ & 0.074 & $* * *$ \\
\hline Tenure squared & & & -0.001 & $* *$ & -0.002 & $*$ & -0.001 & $* *$ & -0.002 & $* *$ & -0.002 & $* *$ \\
\hline Tenure * CEO origin & & & & & 0.004 & & & & & & -0.016 & \\
\hline Tenure * CEO power & & & & & & & -0.102 & $* *$ & & & -0.134 & $* *$ \\
\hline Tenure * Strategic change & & & & & & & & & -0.053 & $*$ & -0.070 & $* *$ \\
\hline CEO origin (insider $=1)$ & 0.012 & & -0.013 & & -0.040 & & -0.020 & & -0.024 & & 0.069 & \\
\hline CEO power & 0.093 & & 0.313 & & 0.313 & & 1.182 & $*$ & 0.239 & & 1.375 & $*$ \\
\hline Strategic change (centered) & 0.120 & & 0.133 & & 0.133 & & 0.133 & & 0.402 & $*$ & 0.487 & $* *$ \\
\hline Firm size (logarithm) & 0.026 & & 0.068 & & 0.067 & & 0.067 & & 0.072 & & 0.078 & \\
\hline CEO duality & 0.136 & & -0.028 & & -0.031 & & -0.028 & & -0.045 & & -0.042 & \\
\hline CEO age & 0.007 & & 0.005 & & 0.005 & & 0.005 & & 0.007 & & 0.008 & \\
\hline Advertising expenditure missing & 0.022 & & 0.019 & & 0.020 & & 0.050 & & 0.008 & & 0.039 & \\
\hline R\&D expenditure missing & -0.312 & $*$ & -0.335 & $* *$ & -0.336 & $* *$ & -0.347 & $* *$ & -0.332 & $* *$ & -0.342 & $* *$ \\
\hline Prior performance & 0.535 & $* * *$ & 0.541 & $* * *$ & 0.541 & $* * *$ & 0.541 & $* * *$ & 0.546 & $* * *$ & 0.550 & $* * *$ \\
\hline Wald chi2 & $1164.95 * * * 1334.20 * * *$ & 1332.30 & $* * * 1379.07 * * * 1410.65$ & $* * *$ & $1538.62 * * *$ \\
\hline N & 1255 & & 1255 & & 1255 & & 1255 & & 1255 & & 1255 & \\
\hline
\end{tabular}


Model 1 is the baseline model. According to the model, previous year's Tobin's q is very highly significant $(\mathrm{p}<0.001)$ and its coefficient is positive as expected. The variable to capture the unavailability of annual $R \& D$ expenditure amount is significant $(\mathrm{p}<0.05)$ and its coefficient is negative. Given the importance of $R \& D$ in the technology hardware and equipment industry, the significance of the variable is not surprising. The significance of previous year's Tobin's q and the dummy variable for missing $R \& D$ expenditure is maintained in all the subsequent models.

Hypothesis 1 predicted that $\mathrm{CEO}$ tenure would have an inverted U-shaped relationship with firm performance. Model 2 tests this hypothesis by adding CEO tenure and its squared term to Model 1 . The squared term is highly significant $(\mathrm{p}<$ 0.01 ) and its coefficient is negative. This result indicates that the relationship between CEO tenure and firm performance is curvilinear and its shape is inverted-U. Therefore, Hypothesis 1 is supported.

Hypothesis 2 predicted that the relationship between CEO tenure and firm performance would be positively moderated by CEO's origin from within the firm. Model 3 tests this hypothesis by adding the interaction term between tenure and CEO origin to Model 2. The coefficient of the term is positive as expected, but it is not statistically significant. Therefore, Hypothesis 2 is not supported.

Hypothesis 3 predicted that the relationship between CEO tenure and firm performance would be negatively moderated by CEO power. Model 4 tests this hypothesis by adding the interaction term between tenure and CEO power to Model 2. The coefficient of the term is negative and significant $(\mathrm{p}<0.01)$ as expected. Therefore, Hypothesis 3 is supported.

Hypothesis 4 predicted that the relationship between CEO tenure and firm performance would be negatively moderated by the degree of strategic change. Model 5 tests this hypothesis by adding the interaction term between tenure and the degree of strategic change to Model 2. The coefficient of the term is negative and significant $(\mathrm{p}<0.05)$ as expected. Therefore, Hypothesis 4 is supported.

Model 6 is the full model including all the interaction terms. The result of this model is consistent with the previous models, insinuating the stability of the statistical results.

\section{Discussion}

It is not surprising to find an inverted-U shaped relationship between CEO tenure and firm performance since past theories and empirical studies largely agree on it. The more important issue to focus on is at what point the peak firm performance occurs in terms of CEO tenure. Henderson et al. (2006) found that the peak firm performance occurred within a year of a new CEO's tenure in the computer industry. The data we employed for this study tell quite a different story. According to the full model (Model 6), the result indicates that the peak performance occurs approximately at the 18th year when all the variables except for CEO origin, tenure and tenure squared are set at their mean and CEO origin is set at zero. Figure 2 shows this graphically. 


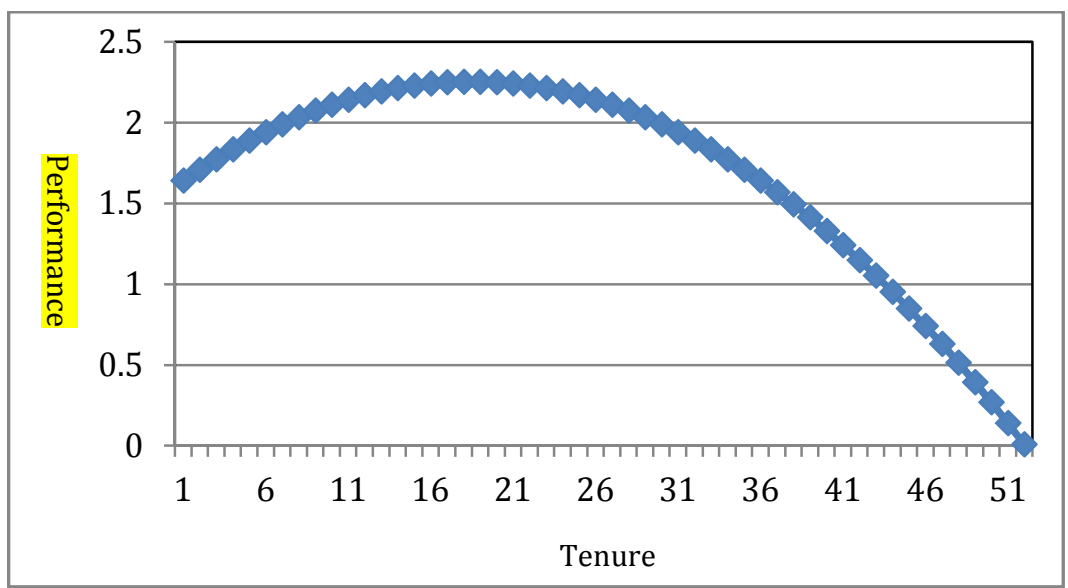

Figure 2 Relationship between Tenure and Firm Performance (Tobin's q)

A direct comparison between the result of Henderson et al. (2006) and that of this study may not be appropriate. Henderson et al., acknowledging that inferior CEOs have a higher probability of being weeded out by boards, employ the sample selection bias correction technique proposed by Lee (1983).We did not use any selectivity correction measure for several reasons. First, CEOs leave their position for a variety of different reasons, not just for their incompetency. They may leave their position due to age-related or health-related reasons including death. They may change jobs for better opportunities. CEOs in larger organizations may experience more pressure for performance. Second, CEOs that are yielding superior firm performance may be pursued or recruited by firms of bigger size and higher status. In a dynamic industry, sustaining superior performance year after year may be extremely hard. Somebody that has been able to do it consistently will be coveted by many firms, which may lead to a fierce competition. Therefore, superior CEOs may have a higher probability of leaving their positions because of better outside opportunities. Third, CEOs that are relatively more powerful in their organizations may last longer because they are capable of influencing their boards' decisions.

To gather more insights on the issue, we estimated the probability of CEO survival (coded 1 if a CEO is still in office the next year, and 0 otherwise) using a logistic regression model. The result is presented in Table 3. It indicates that even though firm performance is significant $(\mathrm{p}<0.01)$ in predicting the probability of CEO survival, CEO duality, CEO age, and firm size are also statistically significant. The fact that the coefficient for CEO age is positive and significant is especially notable in that it may indicate the propensity of younger CEOs to change jobs for better opportunities.

The remaining three hypotheses (Hypothesis 2-4) in the current study concern the boundary condition of the inverted-U shaped relationship between CEO tenure and firm performance, which presupposes the possibility of incompetent CEOs being weeded out. The variables such as CEO duality, CEO origin and CEO power, which were not considered by Henderson et al. (2006), are related not just to the performance of surviving CEOs but also to the probability of them being removed from office. 
Still, 18 years is more than twice as long as the mean value of CEO tenure in the sample (7.3 years). It may be said that most CEOs in the industry does not last long enough to reach their peak performance.

Table 3 Logistic Regression Model for CEO Survival

\begin{tabular}{|l|c|c|}
\hline \multicolumn{2}{|c|}{ Survival } & \multicolumn{2}{c|}{ Coefficient } \\
\hline Firm size & -0.431 & $* *$ \\
\hline CEO duality & 1.370 & $* * *$ \\
\hline CEO age & 0.046 & $* *$ \\
\hline CEO power & -0.783 & \\
\hline CEO origin (insider $=1)$ & 0.177 & \\
\hline Strategic Change & -0.091 & \\
\hline Advertising expenditure missing & -0.002 & \\
\hline R\&D expenditure missing & 0.313 & \\
\hline Firm performance & 0.233 & $* *$ \\
\hline Log likelihood & -432.389 & \\
\hline Chi-square & 96.850 & $* * *$ \\
\hline $\mathrm{N}$ & 1255 & \\
\hline \multicolumn{2}{|c|}{$* p<0.05 ; * * p<0.01 ; * * * p<0.001$} \\
\hline
\end{tabular}

Hypothesis 2 was not supported. This may be the result of the coarse-grained nature of the CEO origin measure. We captured CEO origin based on the traditional dichotomous approach with 2 years as the threshold. However, there is no real consensus on how much time it takes for an outsider to become like an insider (Dalton and Kesner, 1985; Wiersema, 1992; Davidson, Worrell, and Cheng, 1990; Cannella and Lubatkin, 1993; Harris and Helfat, 1997; Zhang and Rajagopalan, 2010; Lubatkin, Chung, Rogers, and Owers, 1986). Moreover, based on this measure, even if an outsider CEO has worked for more than 2 years in the CEO position, he or she is still an outsider.

For future studies, CEO origin may be measured using Karaevli (2007)'s measure of "new CEO outsiderness". His takes into account varying degrees of firm and industry experience of CEOs. Operationally defined as "a continuum ranging from new CEOs who have a greater combination of firm and industry tenure to those who have no experience in the firm and the industry", it is measured as "an index variable by summing the inversed standardized (Z-score) firm and industry tenure of the new CEO" (Karaevli, 2007). One advantage of this measure is that it can be updated yearly to see whether the outside CEO becomes more like the inside CEO as his or her experience in the firm progresses. Another advantage is that it enables us to differentiate between a new CEO from the industry the firm belongs to and a new CEO from a totally different industry.

Hypothesis 3 was supported. To examine the effect of varying levels of CEO power on the relationship between CEO tenure and firm performance, we calculated firm performance on three different levels of CEO power: one standard deviation below 
mean (0.217), mean (0.354), and one standard deviation above mean (0.491).Figure 3 presents this.

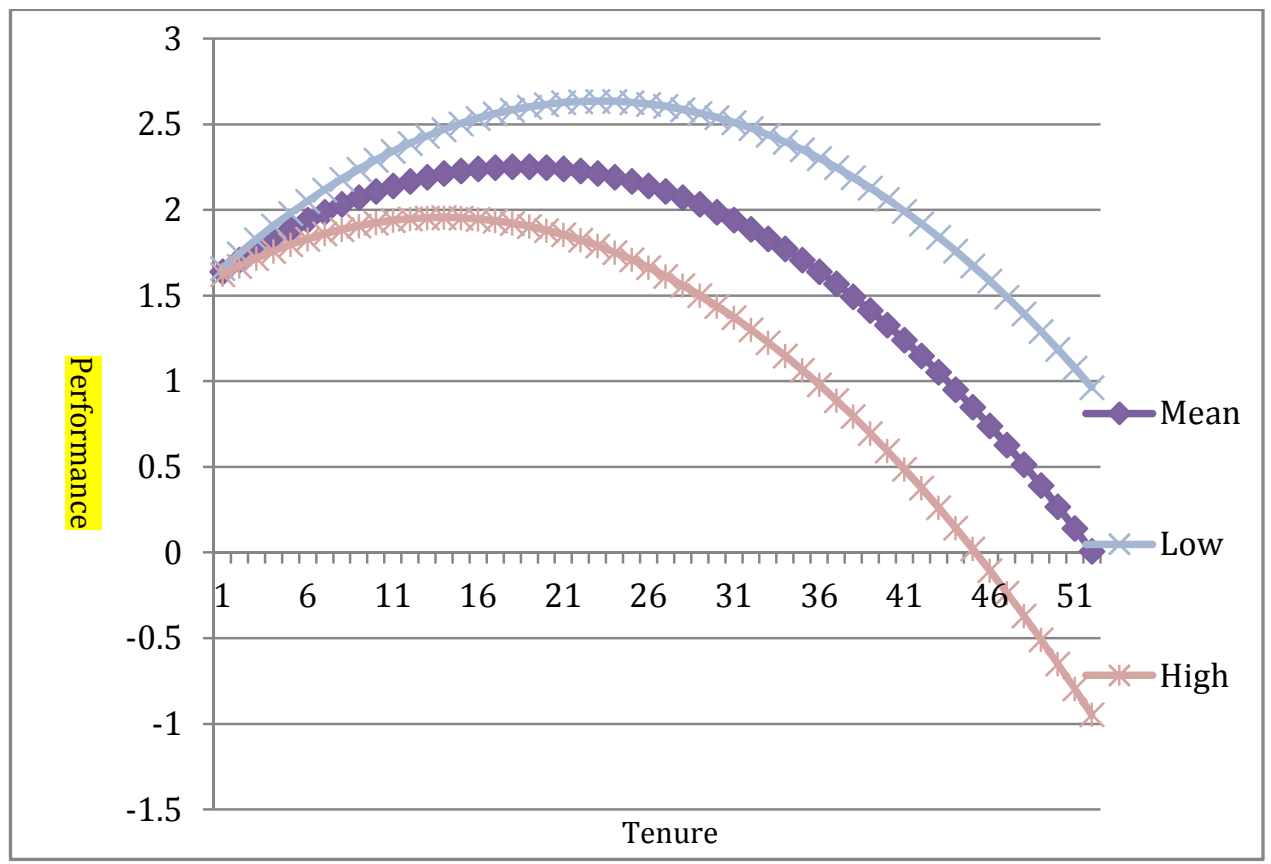

Figure 3 Tenure and Firm Performance on Varying Levels of CEO Power

An interesting finding to note is that CEO power is not statistically significant by itself. Only when it is interacted with CEO tenure does it become significant in estimating firm performance. Therefore, it may be said that even though CEO power per se is not problematic, as a CEO's tenure progresses it has more potential to exert negative influences in terms of CEO paradigm rigidity and strategic persistence.

Hypothesis 4 was also supported. To examine the effect of varying levels of strategic change on the relationship between CEO tenure and firm performance, we calculated firm performance on three different levels of strategic change: one standard deviation below mean (-0.517), mean (0), and one standard deviation above mean (0.517). Figure 4 shows this.

As was the case for CEO power, the degree of strategic change was not statistically significant by itself, but it interacted with CEO tenure to significantly affect firm performance. High degrees of strategic change in early years of a CEO when his or her paradigm is resilient may not be extremely harmful for firm performance. However, high degrees of strategic change in later years may lead to lower performance because of the disconnection between reality and rigidified CEO paradigm. As indicated in Figure 4, firm performance peaked at around year 10 of CEO tenure at the degree of strategic change one standard deviation above mean, whereas firm performance peaked at around year 29 at the degree of strategic change one standard deviation below mean. 


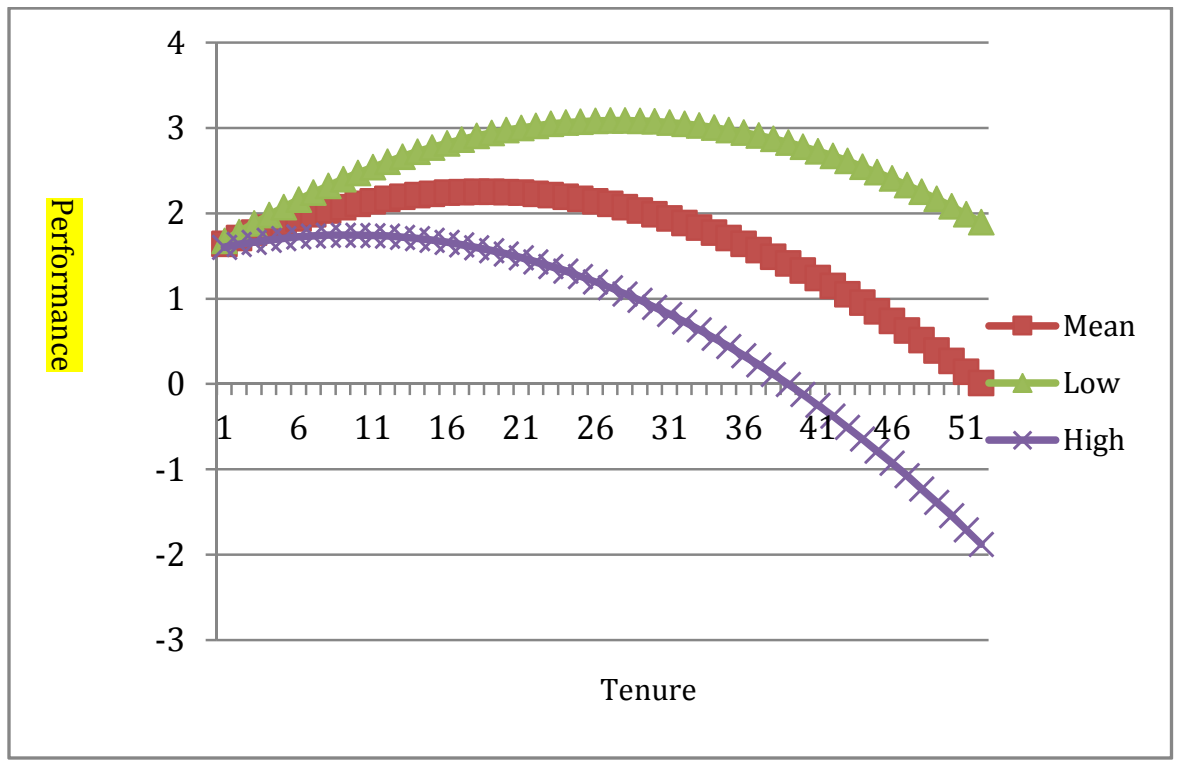

Figure 4 Tenure and Firm Performance on Varying Levels of Strategic Change

\section{Implications and Limitations}

Our results raise the possibility that the negative perception associated with the length of CEO tenure may be overblown. We found that the peak performance for the firm was achieved much later in the CEO's tenure than previously estimated. On average, CEOs left the firm well before the peak performance would have been achieved. We surmise that increasing the degree of internal changes through CEO replacement in a dynamic industry environment may have a negative impact on the firm's performance. While CEO paradigm may eventually go stale as Hambrick and Fukutomi (1991) proposed, having a paradigm may help stabilize the firm to take on dynamic external challenges. The firm's board of directors should take account of conflicting needs and challenges when they consider replacing the current CEO. The board should also recognize that CEO power and the degree of strategic change will increasingly become negative as CEO tenure progresses and find ways to suppress CEO power and enhance the board's monitoring role.

We acknowledge that this study has several limitations that will have to be addressed in future research. First, the three independent variables (CEO origin, CEO power, and the degree of strategic change) have much to be desired in terms of construct validity. CEO origin may be captured better by Karaevli's (2007) measure than the traditional dichotomous measure, as has been discussed already. CEO power may need to be corroborated with something other than the CEO pay slice measure. The literature on CEO hubris (Hayward and Hambrick, 1997) may be helpful in refining the measurement of CEO power. The measure of strategic change has been used widely by scholars in the strategic change literature, but its construct validity is still suspect. Examining a firm's pattern of resource allocation may be one way to measuring the degree of strategic change, but it is not the only way. The degree of strategic change may be revealed partly by the pattern of resource allocation, but the 
same pattern of resource allocation does not guarantee that the degree of strategic change stays the same.

Second, this study did not fully address the potential influence of the market for managerial talents on CEO tenure. Future research may examine the reasons behind CEO turnover and whether the market for managerial talents has a significant impact on CEOs' careers and firm profitability.

Third, the sample that was employed for empirical analyses is too limited to give credibility to the obtained results. It only covered 12 years from 1998 to 2009, which was not enough to accommodate the full tenure of many CEOs in the sample. Data on many more years need to be collected and analyzed to reach more meaningful conclusions.

\section{Conclusion}

The main purpose of this study was to examine whether CEO origin, CEO power, and the level of strategic change moderate the inverted U-shaped relationship between CEO tenure and firm performance in a dynamic industry. To do that, we took the concept of CEO paradigm and focused on the process through which the rigidity of CEO paradigm leads to strategic persistence and ultimately to lower firm performance. We argued that CEO origin, CEO power, and the degree of strategic change moderate the relationship in different mechanisms and directions. Using a sample of firms from the technology hardware and equipment industry in a period from 1998 to 2009, we empirically found that the relationship between CEO tenure and firm performance is inverted-U shaped and CEO power and the degree of strategic change moderate the relationship.

\section{References}

1. Aldrich, H. 1979. Organizations and Environments. Englewood Cliffs, N.J.: Prentice-Hall.

2. Bebchuk, L.A., Cremers, M., \& Peyer, U. 2007. CEO Power. Harvard Law and Economics Discussion Paper No. 601. Available at SSRN: http://ssrn.com/abstract=1030107.

3. Cannella, A. A., Jr., \& Lubatkin, M. 1993. Succession as a sociopolitical process. Academy of Management Journal, 36: 763-793.

4. Carpenter, M. A. 2000. The price of change: The role of CEO compensation in strategic variation and deviation from industry strategy norms. Journal of Management, 26(6): 1179-1198.

5. Dalton, D., \& Kesner, I. F. 1985. Organizational performance as antecedent of Inside/Outside chief executive succession: An empirical assessment. Academy of Management Journal, 28: 749-762.

6. Davidson, W., Worrell, D., \& Cheng, L. 1990. Key executive and stockholder wealth: The influence of successor's origin, position, and age. Journal of Management, 16: 647-664.

7. Dess, G. G., \& Beard, D. W. 1984. Dimensions of organizational task environments. Administrative Science Quarterly, 29(1): 52-73.

8. Finkelstein, S., \& Hambrick, D.C. 1990. Top-management-team tenure and organizational outcomes: The moderating role of managerial discretion. Administrative Science Quarterly, 35: 484-503. 
9. Friedman, S. D., \& Saul, K. 1991. A leader's wake: Organizational member reactions to CEO succession. Journal of Management, 17(3): 619-642.

10. Greene W. 1993. Econometric Analysis. Macmillan: New York.

11. Hambrick, D. C., \& Fukutomi, G. 1991. The seasons of a CEO's tenure. Academy of Management Review, 16: 719-742.

12. Harris, D., \& Helfat, C. 1997. Specificity of CEO human capital and compensation. Strategic Management Journal, 18(11): 895-920.

13. Hayward, M. L. A., \& Hambrick, D. C. 1997. Explaining the premiums paid in large acquisitions: Evidence of CEO hubris. Administrative Science Quarterly, 42: 103-127.

14. Heckman, J. 1979. Sample Selection Bias as a Specification Error. Econometrica, 47:153-161.

15. Helmich, D., \& Brown, W. 1972. Successor type and organizational change in the corporate enterprise. Administrative Science Quarterly, 17: 371-381.

16. Henderson, A. D., Miller, D., \& Hambrick, D. C. 2006. How quickly do CEOs become obsolete? Industry dynamism, CEO tenure, and company performance. Strategic Management Journal, 27: 447-460.

17. Hou, W., Priem, R.L., \& Goranova, M. 2017. Does on size fit all? Investigating pay-future performance relationships over the "seasons" of CEO tenure. Journal of Management, 43-3: 864-891.

18. Karaevli, A. 2007. Performance consequences of new CEO 'outsiderness': Moderating effects of pre- and post-succession contexts. Strategic Management Journal, 28: 681-706.

19. Kor, Y. Y, \& Mahoney, J. T. 2005. How dynamics, management, and governance of resource deployments influence firm-level performance. Strategic Management Journal, 26(5): 489-496.

20. Lee, L. 1983. Generalized econometric models with selectivity. Econometrical, 51: 507-512.

21. Lewellen, W. G., \& Badrinath, S. G. 1997. On the measurement of Tobin's q. Journal of Financial Economics, 44(1): 77-122.

22. Liang, K.-Y., \&Zeger, S. L. 1986. Longitudinal data analysis using generalized linear models. Biometrika, 73(1): 13-22.

23. Lubatkin, M., Chung, K., Rogers, R., \& Owers, J. 1986. The effect of executive succession on stockholder wealth of large corporations. Academy of Management Review, 11: 497-512.

24. Lubatkin, M., Chung, K., Rogers, R., \& Owers, J. 1989. Stockholder reactions to CEO changes in large organizations. Academy of Management Journal, 32: 4768.

25. Miller, D. 1991. Stale in the saddle: CEO tenure and the match between organization and environment. Management Science, 37(1): 34-52.

26. Miller, D., \& Shamsie, J. 2001. Learning across the life cycle: experimentation and performance among the Hollywood studio heads. Strategic Management Journal, 22(8); 725-745.

27. Montgomery, C. A., \& Wernerfelt, B. 1988. Diversification, Ricardian rents and Tobin's q. RAND Journal of Economics, 19(4): 623-632.

28. Penrose, E. 1959. The Theory of the Growth of the Firm. (In the revised edition published in 2009). Oxford, UK: Oxford University Press. 
29. Pfeffer, J., \& Salancik, G. R. 1978. The External Control of Organizations: A Resource Dependence Perspective. New York, NY: Harper and Row.

30. Saidu, S. 2019. CEO characteristics and firm performance: focus on origin, education and ownership. Journal of Global Entrepreneurship Research, 9-29.

31. Shen, W., \&Cannella, A. A., Jr. 2002. Revisiting the performance consequences of CEO succession: The impacts of successor type, post succession senior executive turnover, and departing CEO tenure. Academy of Management Journal, 45(4): 717-733.

32. Sirmon, D. G., Hitt, M. A., \& Ireland, R. D. 2007. Managing firm resources in dynamic environments to create value: Looking inside the black box. Academy of Management Review, 32(1): 273-292.

33. Sirmon, D. G., \& Hitt, M.A. 2009. Contingencies within dynamic managerial capabilities: Interdependent effects of resource investment and deployment on firm performance. Strategic Management Journal, 30(13): 1375-1394.

34. Wiersema, M. F. 1992. Strategic consequences of executive succession within diversified firms. Journal of Management Studies, 29(1): 73-94.

35. Wu, S., Levitas, E., \& Priem, R. L. 2005. CEO tenure and company invention under differing levels of technological dynamism. Academy of Management Journal, 48: 859-873.

36. Zhang, Y. 2006. The presence of a separate COO/president and its impact on strategic change and CEO dismissal. Strategic Management Journal, 27: 283300.

37. Zhang, Y., \& Rajagopalan, N. 2010. Once an outsider, always an outsider? CEO origin, strategic change, and firm performance. Strategic Management Journal, 31: $334-346$

\section{About Our Authors}

Dong Wook Huh is an Assistant Professor of Management at Frostburg State University. He has over 10 years of experience in industry and academia. Dr. Huh has taught courses in management and strategic management. His research interest includes firm diversification, internationalization, business groups, and culture's impact on business. He earned his Ph.D. in management at Texas A\&M University.

Amit Shah is professor of Management at Frostburg State University (FSU) in Maryland. He has over 30 years of experience in industry and academia. Dr. Shah has taught a variety of business courses including management, strategic management, leadership, organizational behavior, and international business. He has presented over 100 papers at various conferences, published over 60 refereed articles in various journals and published proceedings, authored/co-authored two texts published by McGraw-Hill, and conducted workshops for various organizations in the area of business, strategy, and learning. Further he has earned a gold medal as an international researcher and has been honored as a Fellow in AIMS International. 